\title{
Species Variations in the Proximate Composition, Amino Acid Profile, and Protein Quality of the Muscle Tissue of Grass Carp, Bighead Carp, Siberian Sturgeon, and Wels Catfish
}

\author{
Renata Pyz-Lukasik (iD) and Waldemar Paszkiewicz \\ Department of Food Hygiene of Animal Origin, Faculty of Veterinary Medicine, University of Life Sciences in Lublin, \\ Ul. Akademicka 13, 20-950 Lublin, Poland \\ Correspondence should be addressed to Renata Pyz-Łukasik; renata.pyz@up.lublin.pl
}

Received 11 February 2018; Revised 24 April 2018; Accepted 21 May 2018; Published 24 July 2018

Academic Editor: Marina Carcea

Copyright (c) 2018 Renata Pyz-Łukasik and Waldemar Paszkiewicz. This is an open access article distributed under the Creative Commons Attribution License, which permits unrestricted use, distribution, and reproduction in any medium, provided the original work is properly cited.

\begin{abstract}
This study determined the proximate composition, energy value, amino acid profile, and protein quality of the muscle tissue of four food fish species. The fish analyzed contained $78.90-69.89 \%$ water, $18.25-15.69 \%$ protein, and $2.28-12.57 \%$ fat. The energy value of the muscle tissue ranged from 93.50 to $175.83 \mathrm{kcal} / 100 \mathrm{~g}$. The contents of amino acids in $100 \mathrm{~g}$ of protein were 47.64-45.86 g for total essential amino acids (TEAA), 52.36-54.14 g for total neutral amino acids (TNAA), 3.14-2.25 g for total sulphur amino acids (TSAA), and 7.23-7.81 g for total aromatic amino acids (TArAA). The essential amino acid (EAA) composition of the fish was compared with the standard protein, and Chemical Score (CS), Protein Digestibility-Corrected Amino Acid Score (PDCAAS), and Essential Amino Acid Index (EAAI) were calculated. The quality of the muscle tissue proteins of all four fish species was high. These fish can constitute a healthy addition to the human diet.
\end{abstract}

\section{Introduction}

The species of fish markedly affects the proximate composition and amino acid profile of their muscle tissue. Depending on the species, fish muscle tissue contains $12.2-21.79 \%$ protein [1-6], $0.08-13.1 \%$ fat, and $67.3-86.7 \%$ water $[1,4,7,8]$. The energy value of the muscle tissue of different fish species, which depends on the proportion of its basic components, ranged from 210.7 to $797.5 \mathrm{~kJ} / 100 \mathrm{~g}[4,9,10]$.

Depending on the species, the contents of particular essential amino acids in the muscle tissue ( $\mathrm{g} / 100 \mathrm{~g}$ protein) freshwater and marine fish varied, respectively, in the ranges of $1.4-5.3$ and $0.5-7.9$ for histidine, $0.2-6.2$ and $0.3-5.2$ for isoleucine, $0.4-9.0$ and $0.7-10.4$ for leucine, $0.3-4.8$ and 0.9-16.1 for lysine, $0.1-2.85$ and $0.4-4.0$ for methionine, $0.1-0.2$ and $0.04-0.6$ for cysteine, $0.3-6.3$ and $0.5-4.3$ for phenylalanine, $0.9-1.3$ and $0.2-1.5$ for tyrosine, $0.3-5.9$ and $0.5-7.9$ for threonine, $0.2-7.3$ and $0.5-8.6$ for valine, and 0.1-1.4 and 1.2-2.3 for tryptophan [11].
The quality of protein is determined by its content of amino acids. This quality is evaluated by comparing the essential amino acid profile of the protein tested with a standard protein. At present, the recommended amino acid scoring pattern for evaluating protein quality is the standard protein recommended by the FAO Expert Consultation on Protein Quality Evaluation in Human Nutrition from 2011 (published in FAO Food and Nutrition Paper 92 from 2013 [12]). It takes into account the essential amino acid requirements of different age groups, that is, infants, older children, adolescents, and adults. In addition, protein quality is measured by indices, such as Chemical Score (CS), Protein Digestibility-Corrected Amino Acid Score (PDCAAS), and Essential Amino Acid Index (EAAI) $[13,14]$. CS indicates the scarcest amino acid in a given protein, the so-called "limiting amino acid," which is determined by comparing the contents of particular essential amino acids in the protein tested and in the reference protein. EAAI, like CS, is based on a comparison of the 
essential amino acid composition of the protein evaluated and the standard protein, but it also takes into account the presence of all essential amino acids required for protein synthesis. Hence the protein quality, as assessed by EAAI, depends on the contents of all these amino acids, and not only on the level of the limiting amino acid. Similarly to the other two indices, PDCAAS depends on the content of particular essential amino acids in a given protein measured against the standard protein, but it also takes into account protein digestibility.

Fish can play a vital role as an important source of protein in human nutrition. Therefore, there is a need to generate and document nutritional information on the numerous species of food fishes available [11]. Grass carp (Ctenopharyngodon idella), bighead carp (Aristichthys nobilis), Siberian sturgeon (Acipenser baerii), and wels catfish (Silurus glanis) are popular food fish of commercial significance in many countries (www.fao.org/fishery/statistics/). Grass carp and bighead carp are herbivorous, whereas Siberian sturgeon and wels catfish are predators. The aforementioned species are freshwater fish.

The objective of the study was to determine the proximate composition, energy value, and amino acid profile of the muscle tissue of these four important food fish and to evaluate the quality of their protein in order to compare their nutritional value.

\section{Materials and Methods}

2.1. Sampling and Morphometrical Measurements. The research material consisted of the muscle tissue of grass carp $(n=12)$, bighead carp $(n=12)$, Siberian sturgeon $(n=6)$, and wels catfish $(n=12)$. The fish came from fish farms located in Eastern Poland and were obtained in the winter. The fish ate natural alimentation which was in the pond (typically for herbivorous fish i.a. grass carp and bighead carp and predatory fish i.a. Siberian sturgeon and wels catfish) and did not receive any industrial feed. After slaughter, the body weight and length of each fish were measured, and the fish were transported to the laboratory within one hour (at $0-4^{\circ} \mathrm{C}$ ) and eviscerated. The carcasses were weighed to determine the carcass yield. A laboratory sample made by two fillets from each fish was ground twice in a meat mincer with a disc of a $2 \mathrm{~mm}$ mesh diameter. After 1 and 2 milling operations, the sample was blended to achieve homogeneity. The size of analytical samples depended on the kind of determination carried out and was consistent with methodological recommendations. The proximate composition and hydroxyproline content were measured on fresh muscle tissue samples, whereas the amino acid profile was determined in samples stored at $-36^{\circ} \mathrm{C}$.

\subsection{Proximate Composition and Content of Hydroxyproline.} The proximate composition of the muscle tissue was determined in accordance with international standards (ISO). The moisture content was measured by drying the samples in an oven at $103^{\circ} \mathrm{C} \pm 2^{\circ} \mathrm{C}$ to constant weight [15]. The fat content was determined by the ether extraction method with a Tecator Soxtec System HT 21045 Extraction Unit [16]. The ash content was established by sample incineration in a muffle furnace at $550^{\circ} \mathrm{C} \pm 25^{\circ} \mathrm{C}$ until the resultant ash was light grey in color [17], and the protein content was estimated by the Kjeldahl method $(N \times 6.25)$ with a Tecator Kjeltec System 1026 distilling unit after acid digestion [18]. In addition, the hydroxyproline concentration was established [19].

2.3. Amino Acid Composition. The amino acid profile was obtained by ion-exchange chromatography. The amino acid content in the samples (except for cystine, methionine, and tryptophan) was determined after acid hydrolysis with $6 \mathrm{~N} \cdot \mathrm{HCl}$ at $110^{\circ} \mathrm{C}$ for $20 \mathrm{~h} \mathrm{[20].} \mathrm{Cystine} \mathrm{and} \mathrm{methionine} \mathrm{were}$ measured as cysteic acid and methionine sulphone, respectively, by performic acid oxidation before hydrolysis with $6 \mathrm{~N} \cdot \mathrm{HCl}[21]$. Tryptophan was quantified using alkaline hydrolysis with $\mathrm{Ba}(\mathrm{OH})_{2}$ at $110^{\circ} \mathrm{C}$ for $20 \mathrm{~h} \mathrm{[22].} \mathrm{Chro-}$ matographic analysis was performed in an AAA 400 Ingos automatic amino acid analyzer (Czech Republic, Prague) with an ion-exchange column and UV-VIS detector. The amino acid content in the samples was determined through comparison with the external standard after allowing for recoveries.

All chemical analyses were conducted in duplicate for each sample.

2.4. Carcass Yield, Caloric Value, CS, EAAI, and PDCAAS. Carcass yield, caloric value, CS, EAAI, and PDCAAS were calculated as follows $[13,14,23]$ :

Carcass yield $\%=$ carcass weight with head/total weight $\times 100 \%$.

Energy values $=4 \mathrm{kcal} / \mathrm{g}$ or $17 \mathrm{~kJ} / \mathrm{g}$ for protein and $9 \mathrm{kcal} / \mathrm{g}$ or $37 \mathrm{~kJ} / \mathrm{g}$ for fat.

$\mathrm{CS}=\mathrm{mg}$ of an amino acid in $1 \mathrm{~g}$ of the protein tested/mg of the same amino acid in $1 \mathrm{~g}$ of the reference protein. CS is expressed either as a ratio to unity or on a percentage scale.

$$
\begin{aligned}
\mathrm{EAAI} & =n^{\log \mathrm{EAA}}, \\
\text { where } \log \mathrm{EAA} & =\frac{1}{n}\left(\log \frac{100 a_{1}}{a_{1 S}}+\cdots+\log \frac{100 a_{n}}{a_{n S}}\right) .
\end{aligned}
$$

$\mathrm{PDCAAS}=\mathrm{mg}$ of limiting amino acid in $1 \mathrm{~g}$ of the protein tested/mg of the same amino acid in $1 \mathrm{~g}$ of the reference protein $\times$ true protein digestibility. The score is expressed as a decimal, but it may also be expressed in percentage terms.

2.5. Statistical Analysis. All data are presented as means and standard deviations (SD). The statistical analysis of the data was performed by the Statistica software ver. 6.0 and oneway ANOVA. Differences between the means were tested for statistical significance by the post hoc multiple-comparison test. The chemical composition, morphometrical measurements, and yield were evaluated by Tukey's test (for unequal 
TABLE 1: Morphometrical measurements and yield of grass carp, bighead carp, Siberian sturgeon, and wels catfish (mean value \pm SD).

\begin{tabular}{lcccc}
\hline & & & Species \\
& Grass carp $(n=12)$ & Bighead carp $(n=12)$ & Siberian sturgeon $(n=6)$ & Wels catfish $(n=12)$ \\
\hline Weight $(\mathrm{kg})$ & $2.04^{\mathrm{a}} \pm 0.55$ & $2.64^{\mathrm{b}} \pm 0.30$ & $2.17^{\mathrm{ab}} \pm 0.82$ & $2.68^{\mathrm{b}} \pm 0.38$ \\
Length $(\mathrm{cm})$ & $54.92^{\mathrm{a}} \pm 5.58$ & $50.38^{\mathrm{a}} \pm 1.58$ & $79.83^{\mathrm{b}} \pm 9.02$ & $74.00^{\mathrm{b}} \pm 3.72$ \\
Yield $(\%)$ & $90.40^{\mathrm{ac}} \pm 1.32$ & $89.79^{\mathrm{a}} \pm 0.99$ & $85.94^{\mathrm{b}} \pm 2.06$ & $91.50^{\mathrm{c}} \pm 1.22$ \\
\hline
\end{tabular}

Mean values in rows marked with different letters differ significantly at $p<0.05$.

TABle 2: Proximate composition, hydroxyproline level, and energy value of muscles of grass carp, bighead carp, Siberian sturgeon, and wels catfish (mean value \pm SD).

\begin{tabular}{lcccc}
\hline & & \multicolumn{3}{c}{ Species } \\
& Grass carp $(n=12)$ & Bighead carp $(n=12)$ & Siberian sturgeon $(n=6)$ & Wels catfish $(n=12)$ \\
\hline Moisture (\%) & $78.06^{\mathrm{a}} \pm 1.40$ & $73.56^{\mathrm{b}} \pm 2.01$ & $69.89^{\mathrm{c}} \pm 2.11$ & $78.90^{\mathrm{a}} \pm 2.44$ \\
Protein (\%) & $18.25^{\mathrm{a}} \pm 0.41$ & $15.98^{\mathrm{b}} \pm 0.98$ & $15.69^{\mathrm{b}} \pm 0.83$ & $16.24^{\mathrm{b}} \pm 0.60$ \\
Fat (\%) & $2.28^{\mathrm{a}} \pm 1.0$ & $8.93^{\mathrm{b}} \pm 2.31$ & $12.57^{\mathrm{c}} \pm 2.20$ & $3.78^{\mathrm{a}} \pm 2.09$ \\
Ash (\%) & $1.22^{\mathrm{a}} \pm 0.04$ & $1.10^{\mathrm{b}} \pm 0.05$ & $1.10^{\mathrm{b}} \pm 0.08$ & $0.97^{\mathrm{c}} \pm 0.02$ \\
Hydroxyproline (\%) & $0.09^{\mathrm{a}} \pm 0.01$ & $0.05^{\mathrm{b}} \pm 0.01$ & $0.09^{\mathrm{a}} \pm 0.02$ & $0.09^{\mathrm{a}} \pm 0.01$ \\
Energy value (kcal/100g) & $93.50^{\mathrm{a}} \pm 8.72$ & $144.27^{\mathrm{b}} \pm 20.58$ & $175.83^{\mathrm{c}} \pm 17.75$ & $99.14^{\mathrm{a}} \pm 19.41$ \\
\hline
\end{tabular}

Mean values in rows marked with different letters differ significantly at $p<0.05$.

sample sizes) and amino acids by Duncan's test. Differences between the groups with $p<0.05$ were considered statistically significant.

\section{Results and Discussion}

The mean body weight, length, and carcass yield of the examined fish species are presented in Table 1. Carcass yield ranged from $85.94 \%$ for Siberian sturgeon to $91.50 \%$ for wels catfish. Carcass yields similar to those obtained in the present study were reported for farmed sturgeon hybrids $(89.4 \%)$ [24], wild and cultivated pikeperch $(88.06 \%$ and $83.82 \%$, resp.) [25], and Atlantic salmon (87.5\%) [26].

The proximate composition, hydroxyproline content, and energy value of the four fish species are presented in Table 2. The protein level in their muscle tissue ranged from $15.69 \%$ to $18.25 \%$. In grass carp, it was higher than in bighead carp, Siberian sturgeon, and wels catfish by $12 \%, 14 \%$, and $11 \%$, respectively, and protein levels in these three species were similar. The fat content in the muscle tissue of the four species ranged from $2.28 \%$ to $12.57 \%$. Siberian sturgeon contained significantly more fat compared to bighead carp, wels catfish, and grass carp, whereas the fat contents in wels catfish and grass carp were similar and significantly lower than in the bighead carp. Among the four fish species analyzed, significant differences in the fat content amounted to $29-82 \%$. The fat content in fish muscle serves as the basis for the classification of fish as lean (containing up to $2 \%$ of fat), mediumfat ( $2-7 \%$ of fat), fat ( $7-15 \%$ of fat), and high-fat (above $15 \%$ of fat) [27]. According to this classification, the grass carp and wels catfish analyzed in this study belonged to the medium-fat category, whereas the bighead carp and Siberian sturgeon fell into the fat category. The water content in the muscle tissue varied between $69.89 \%$ and $78.90 \%$. It was similar for wels catfish and grass carp, both of which had significantly greater water content than bighead carp and Siberian sturgeon. The lowest water content was found in the Siberian sturgeon's muscle tissue. Significant differences in the water content of these fish were $1-11 \%$. The ash content in the muscle tissue of the four fish species varied from $0.97 \%$ to $1.22 \%$ (with differences 10\%-20\%). It was the highest in grass carp, similar in bighead carp and Siberian sturgeon, and the lowest in wels catfish. The hydroxyproline content ranged from $0.05 \%$ in bighead carp muscle tissue to $0.09 \%$ in the other fish species, which suggests that the collagen content in the muscle tissue of these fish was low. The energy value of their muscle tissue varied between $93.50 \mathrm{kcal} / 100 \mathrm{~g}$ and $175.83 \mathrm{kcal} / 100 \mathrm{~g}$ $(394.6-731.8 \mathrm{~kJ} / 100 \mathrm{~g})$. It was highest for the Siberian sturgeon, followed by bighead carp, and lowest for grass carp and wels catfish, two species with similar energy values. The energy value of the muscle tissue of the cultured sturgeon was reported as $105-208 \mathrm{kcal} / 100 \mathrm{~g}(444-866 \mathrm{~kJ} / 100 \mathrm{~g})$ [28], and the values obtained for sturgeon in this research were in the same range. The four fish species analyzed in this paper had lower energy values than the Baltic salmon $(797.54 \mathrm{~kJ} / 100 \mathrm{~g})$ but higher energy values than the Baltic cod $(295.8 \mathrm{~kJ} / 100 \mathrm{~g})$, farmed fish imported from Vietnam and China, such as sutchi catfish and tilapia (267.4 kJ/100 g and $352.8 \mathrm{~kJ} / 100 \mathrm{~g}$, resp.), or oceanic fish imported from China, such as walleye Pollock and sole $(210.7 \mathrm{~kJ} / 100 \mathrm{~g}$ and $246.3 \mathrm{~kJ} / 100 \mathrm{~g}$, resp.) [4].

Differences in the proximate composition of the muscle tissue of grass carp, bighead carp, Siberian sturgeon, and wels catfish have also been reported by other authors. The muscle tissue of grass carp originating from the Republic of Serbia [6], Iran [29], and Brasil [30] contained, respectively, $14.73 \%$, $17.41 \%$, and $19.31 \%$ of protein and $8.02 \%, 2.35 \%$, and $1.80 \%$ of fat. The levels of protein and fat determined in grass carp in the present study differed from the above values (except for the fat level noted in grass carp from Iran). The muscle tissue of bighead carp from Bulgaria contained 15-16.75\% of protein and $2.24-4.5 \%$ of fat [3], whereas the corresponding values for bighead carp from the Republic of Serbia were $18.03 \%$ and 
TABLe 3: Amino acid profile of protein of grass carp, bighead carp, Siberian sturgeon, and wels catfish (mean value \pm SD).

\begin{tabular}{|c|c|c|c|c|c|}
\hline Amino acid ( $\mathrm{g} / 100 \mathrm{~g}$ protein) & Grass carp $(n=6)$ & Bighead carp $(n=6)$ & Siberian sturgeon $(n=6)$ & Wels catfish $(n=6)$ & Standard* \\
\hline Isoleucine (Ile) & $4.28^{\mathrm{a}} \pm 0.08$ & $4.24^{\mathrm{a}} \pm 0.11$ & $4.33^{\mathrm{a}} \pm 0.09$ & $4.35^{\mathrm{a}} \pm 0.11$ & 3.0 \\
\hline Leucine (Leu) & $7.81^{\mathrm{a}} \pm 0.10$ & $7.89^{\mathrm{ab}} \pm 0.15$ & $7.97^{\mathrm{b}} \pm 0.13$ & $7.98^{\mathrm{b}} \pm 0.10$ & 6.1 \\
\hline Lysine (Lys) & $9.83^{\mathrm{a}} \pm 0.11$ & $9.69^{\mathrm{a}} \pm 0.17$ & $10.02^{\mathrm{b}} \pm 0.17$ & $9.71^{\mathrm{a}} \pm 0.07$ & 4.8 \\
\hline Methionine (Met) & $2.77^{\mathrm{a}} \pm 0.22$ & $2.30^{\mathrm{bc}} \pm 0.19$ & $2.44^{\mathrm{b}} \pm 0.41$ & $2.05^{\mathrm{c}} \pm 0.13$ & $2.3^{1}$ \\
\hline Cysteine (Cys) & $0.37^{\mathrm{a}} \pm 0.04$ & $0.24^{\mathrm{b}} \pm 0.05$ & $0.23^{\mathrm{b}} \pm 0.05$ & $0.20^{\mathrm{b}} \pm 0.04$ & \\
\hline Phenylalanine (Phe) & $3.97^{\mathrm{a}} \pm 0.13$ & $4.02^{\mathrm{ab}} \pm 0.06$ & $4.25^{\mathrm{c}} \pm 0.06$ & $4.10^{\mathrm{b}} \pm 0.05$ & $4.1^{2}$ \\
\hline Tyrosine (Tyr) & $3.26^{\mathrm{a}} \pm 0.12$ & $3.35^{\mathrm{a}} \pm 0.09$ & $3.57^{\mathrm{b}} \pm 0.06$ & $3.26^{\mathrm{a}} \pm 0.08$ & \\
\hline Threonine (Thr) & $4.75^{\mathrm{ab}} \pm 0.05$ & $4.71^{\mathrm{a}} \pm 0.11$ & $4.86^{\mathrm{b}} \pm 0.13$ & $5.15^{\mathrm{c}} \pm 0.11$ & 2.5 \\
\hline Tryptophan (Try) & $3.02^{\mathrm{a}} \pm 0.41$ & $3.04^{\mathrm{a}} \pm 0.52$ & $1.80^{\mathrm{b}} \pm 0.33$ & $1.98^{\mathrm{b}} \pm 0.15$ & 0.66 \\
\hline Valine (Val) & $4.91^{\mathrm{a}} \pm 0.06$ & $4.93^{\mathrm{a}} \pm 0.11$ & $4.85^{\mathrm{a} \pm 0.10}$ & $4.74^{\mathrm{b}} \pm 0.08$ & 4.0 \\
\hline Histidine (His) & $2.69^{\mathrm{a}} \pm 0.09$ & $2.67^{\mathrm{a}} \pm 0.09$ & $3.29^{\mathrm{b}} \pm 0.13$ & $2.34^{\mathrm{c}} \pm 0.02$ & 1.6 \\
\hline TEAA & $47.64^{\mathrm{a}}$ & $47.08^{\mathrm{a}}$ & $47.62^{\mathrm{a}}$ & $45.86^{\mathrm{b}}$ & 29.06 \\
\hline Aspartic acid (Asp) & $10.30 \pm 0.10$ & $10.28 \pm 0.17$ & $10.20 \pm 0.18$ & $10.52 \pm 0.17$ & \\
\hline Arginine (Arg) & $6.59 \pm 0.18$ & $6.63 \pm 0.13$ & $6.66 \pm 0.09$ & $6.63 \pm 0.13$ & \\
\hline Serine (Ser) & $4.17 \pm 0.03$ & $4.21 \pm 0.07$ & $4.49 \pm 0.06$ & $4.26 \pm 0.07$ & \\
\hline Glutamic acid (Glu) & $15.06 \pm 0.23$ & $15.11 \pm 0.73$ & $14.91 \pm 0.26$ & $15.98 \pm 0.15$ & \\
\hline Proline (Pro) & $4.70 \pm 0.21$ & $4.81 \pm 0.26$ & $4.80 \pm 0.26$ & $5.16 \pm 0.22$ & \\
\hline Glycine (Gly) & $5.45 \pm 0.32$ & $5.67 \pm 0.18$ & $5.21 \pm 0.29$ & $5.43 \pm 0.32$ & \\
\hline Alanine (Ala) & $6.09 \pm 0.06$ & $6.20 \pm 0.07$ & $6.10 \pm 0.10$ & $6.16 \pm 0.07$ & \\
\hline NEAA & $52.36^{\mathrm{a}}$ & $52.92^{\mathrm{a}}$ & $52.38^{\mathrm{a}}$ & $54.14^{\mathrm{b}}$ & \\
\hline TSAA & $3.14^{\mathrm{a}}$ & $2.53^{b c}$ & $2.67^{\mathrm{b}}$ & $2.25^{\mathrm{c}}$ & \\
\hline TArAA & $7.23^{\mathrm{a}}$ & $7.37^{\mathrm{a}}$ & $7.81^{\mathrm{b}}$ & $7.36^{\mathrm{a}}$ & \\
\hline
\end{tabular}

Mean values in rows marked with different letters differ significantly at $p<0.05 .{ }^{*}$ Recommended amino acid scoring pattern for adult. ${ }^{1} \mathrm{Met}+\mathrm{Cys} .{ }^{2} \mathrm{Phe}+\mathrm{Tyr}$. TEAA: total essential amino acids; NEAA: nonessential amino acids; TSAA: total sulphur amino acids; TArAA: total aromatic amino acids.

$6.29 \%$ [6]. In the present study, this fish species showed a higher fat content, whereas the protein level was within the range reported by Hadjinikolova et al. [3]. The muscle tissue of sturgeon from Northern Italy [28] and sturgeon hybrid from Germany [24] contained more protein $(19.23 \%$ and $18.3 \%$, resp.) and less fat (7.63\% and 6.3\%, resp.) than the Siberian sturgeon tissue examined in this study. In the muscle tissue of sturgeon from Poland analyzed by other authors [31], the protein content reached $14.3-16.5 \%$ and the fat content $6.4-$ 9.5\%. The protein level determined for this species in the present study remained within the above range, but the fat content was higher. Wels catfish from the Republic of Serbia [6] and Greece [32] contained, respectively, $17.34 \%$ and $18 \%$ of protein and $3.96 \%$ and $3.2-3.8 \%$ of fat. The present study of this species showed lower protein content and a fat level within the above range of values. The protein content determined here for wels catfish muscle tissue was also consistent with the range of values provided in nutrition tables (13.4-16.5\%) [23]. Differences in the levels of basic components in the muscle tissue of fish have been confirmed by a number of authors. The proximate composition of muscle tissue depends on the species, age, diet, season, source, and geographical origin [6, 33-36].

The amino acid profile of the muscle tissue protein analyzed is presented in Table 3. The muscle tissue of grass carp, bighead carp, Siberian sturgeon, and wels catfish contained the following amounts of particular essential amino acids per $100 \mathrm{~g}$ protein: $4.24-4.35 \mathrm{~g}$ isoleucine (with differences $0.5-2.6 \%$ ), 7.81-7.98 g leucine (with differences 0.2-2.2\%), 9.69-10.02 g lysine (with differences 1.9-3.3\%), 2.05-2.77g methionine (with differences 12-26\%), 0.20$0.37 \mathrm{~g}$ cysteine (with differences 35.2-46\%), 3.97-4.25 g phenylalanine (with differences 3.6-6.6\%), 3.26-3.57g tyrosine (with differences 6.2-8.7\%), 4.71-5.15g threonine (with differences 5.7-8.6\%), 1.80-3.04g tryptophan (with differences $0.7-40.8 \%$ ), 4.74-4.93 g valine (with differences 0.5-3.9\%), and 2.34-3.29g histidine (with differences 18.3-28.9\%). The sums of essential amino acids in the muscle tissue of grass carp, bighead carp, and Siberian sturgeon were similar (47.64-47.08 g per $100 \mathrm{~g}$ of protein) but significantly higher than TEAA in the muscle tissue of wels catfish $(45.86 \mathrm{~g})$. In all fish, lysine was the most abundant essential amino acid (9.69-10.02 g), and cysteine was the least abundant $(0.20-0.37 \mathrm{~g})$. Isoleucine was the only essential amino acid whose content was comparable in all four species. The sulphur amino acid content in muscle tissue was highest for grass carp $(3.14 \mathrm{~g})$, followed by Siberian sturgeon and bighead carp (2.76 g and $2.53 \mathrm{~g}$, resp.), and lowest for wels catfish (2.25 g). The level of aromatic amino acids was significantly higher in Siberian sturgeon muscle tissue $(7.81 \mathrm{~g})$ than in the muscle tissue of the other fish species (7.23-7.37 g). The muscle tissue of herbivorous species, that is, grass carp and bighead carp, differed in the content of methionine and cysteine, but the levels of the other amino acids were comparable. The muscle tissue of predatory fish, namely, Siberian sturgeon and wels catfish, contained similar amounts of leucine, cysteine, and tryptophan, whereas the contents of lysine, methionine, phenylalanine, tyrosine, threonine, valine, and histidine varied significantly. The sum of nonessential amino acids was higher in wels catfish muscle tissue $(54.14 \mathrm{~g} / 100 \mathrm{~g}$ of protein) than in the other three fish species, in which these values were comparable. Among the nonessential amino acids, the levels of glutamic acid were the highest (14.91-15.98 g), and those of serine the lowest $(4.17-4.49 \mathrm{~g})$. The sum of 
TABle 4: CS (Chemical Score) and EAAI (Essential Amino Acid Index) for protein of grass carp, bighead carp, Siberian sturgeon, and wels catfish (\%).

\begin{tabular}{|c|c|c|c|c|c|}
\hline Amino acid & Grass carp & Bighead carp & Siberian sturgeon & Wels catfish & Standard ${ }^{*}$ \\
\hline Ile & 143 & 141 & 144 & 145 & 3.0 \\
\hline Leu & 128 & 129 & 131 & 131 & 6.1 \\
\hline Lys & 205 & 202 & 209 & 202 & 4.8 \\
\hline Met + Cys & 137 & 110 & 116 & 98 & 2.3 \\
\hline Phe + Tyr & 176 & 180 & 191 & 180 & 4.1 \\
\hline Thr & 190 & 188 & 194 & 206 & 2.5 \\
\hline Try & 458 & 461 & 273 & 300 & 0.66 \\
\hline Val & 123 & 123 & 121 & 119 & 4.0 \\
\hline His & 168 & 167 & 206 & 146 & 1.6 \\
\hline EAAI & 139 & 136 & 134 & 128 & \\
\hline
\end{tabular}

* Recommended amino acid scoring pattern for adult.

essential amino acids in the muscle tissue of cultured sturgeon (47.15 g/100 g of protein) reported by Badiani et al. [28] was comparable to that found in this fish species in the present study. The greatest difference relative to their findings was a considerably higher tryptophan content determined in the present study. In the muscle tissue protein of fish caught in the Vistula Lagoon [37], such as herring, perch, pikeperch, and eel, the sum of essential amino acids (without histidine) ranged from $39.93 \mathrm{~g}$ (per $100 \mathrm{~g}$ of protein) for eel to $45.36 \mathrm{~g}$ for pikeperch. As in the present study, the content of lysine was the highest. The fish from the Vistula Lagoon had a higher content of sulphur amino acids (3.93-4.20 g) and, with the exception of pikeperch, a lower content of aromatic amino acids (6.42$6.69 \mathrm{~g}$ ) compared with grass carp, bighead carp, Siberian sturgeon, and wels catfish. The sum of essential amino acids (except tryptophan, which was not determined) in the muscle tissue protein of marine fish, such as Clupea harengus, Scomber scombrus, and Urophycis tenuis, varied from $40.73 \mathrm{~g}$ to $44.04 \mathrm{~g}$ per $100 \mathrm{~g}$ of protein [38]. As in the present study, the quantity of lysine was the highest and that of cysteine the lowest. The contents of sulphur amino acids (3.44-3.69 g) and aromatic amino acids (10.24-11.24g) in these fish species were higher than in grass carp, bighead carp, Siberian sturgeon, and wels catfish. EL oudiani and Moujahed [39] reported the sum of essential amino acids (with histidine, tryptophan not determined) in Scomber scombrus as $38.55 \mathrm{~g} / 100 \mathrm{~g}$ of protein and the contents of sulphur amino acids and aromatic amino acids as $3.34 \mathrm{~g}$ and $9.62 \mathrm{~g}$, respectively. According to these results, the muscle tissue of grass carp, bighead carp, Siberian sturgeon, and wels catfish contained less sulphur amino acids and aromatic amino acids compared with Scomber scombrus. In Clarias anguillaris, Oreochromis niloticus, and Cynoglossus senegalensis, the sum of essential amino acids (without tryptophan) amounted to $30.0-31.7 \mathrm{~g} / 100 \mathrm{~g}$ of protein [40]. This suggests that, although tryptophan was not determined, TEAA values in those fish species were lower than the values found in the present study in the muscle tissue of grass carp, bighead carp, Siberian sturgeon, and wels catfish.

The quality of protein was evaluated against the standard protein with the use of CS, PDCAAS, and EAAI. Compared with the standard protein recommended by FAO Expert Consultation on Protein Quality Evaluation in Human Nutrition from 2011, the levels of all essential amino acids in the grass carp, bighead carp, Siberian sturgeon, and wels catfish were higher, with the exception of the methionine + cysteine level in wels catfish $(2.25 \mathrm{~g} / 100 \mathrm{~g}$ of protein, which was similar) (Table 3 ). The muscle tissue protein of grass carp, bighead carp, Siberian sturgeon, and wels catfish fully measured up to the standard protein. The limiting amino acid (CS) was methionine + cysteine in the protein of wels catfish, bighead carp, and Siberian sturgeon (CS: 98\%, 110\%, and $116 \%$, resp.) and valine in the protein of grass carp (CS: $123 \%)$. The level of the limiting amino acid was lower than in the standard protein only for wels catfish, whereas for bighead carp, Siberian sturgeon, and grass carp, the limiting amino acid was more abundant compared to the standard (Table 4).

PDCAAS (Protein Digestibility-Corrected Amino Acid Score) values for essential amino acids ranged from $92 \%$ for methionine + cysteine in the muscle tissue protein of wels catfish to over $100 \%$ for all amino acids in the muscle tissue protein of the other species (Table 5).

Table 5 contains data regarding the limiting amino acids, as well as the 11 essential amino acids. In order to provide more detailed information, the values of particular essential amino acids exceeding 100 have not been rounded. Protein digestibility-corrected amino acid scores above $100 \%$ would be considered as $100 \%$ [14]. The truncation of PDCAAS values to $100 \%$ is acceptable only if the protein is used as the sole protein source in the diet. Truncated values should not be used in evaluating the nutritional significance of proteins in mixed diets [41]. Both PDCAAS and CS indicated a lower methionine + cysteine content in the protein of wels catfish compared with the standard protein. EAAI ranged between 128 in wels catfish and 139 in grass carp, which shows that the sum of essential amino acids in the protein of grass carp, bighead carp, Siberian sturgeon, and wels catfish was higher than it was in the reference standard protein (Table 4). Thus, EAAI did not confirm the lower methionine + cysteine content in the protein of wels catfish. In the available literature, the values of CS, EAAI, and PDCAAS for fish muscle tissue proteins do not refer to the standard assumed in this research and therefore cannot be compared with the results obtained for the fish species analyzed.

The contents of particular essential amino acids in $100 \mathrm{~g}$ of the muscle tissue for the four fish species and the 
TAble 5: PDCAAS (Protein Digestibility-Corrected Amino Acid Score) for protein of grass carp, bighead carp, Siberian sturgeon, and wels catfish (\%).

\begin{tabular}{|c|c|c|c|c|c|}
\hline Amino acid & Grass carp & Bighead carp & Siberian sturgeon & Wels catfish & Standard* \\
\hline Ile & 134 & 133 & 136 & 136 & 3.0 \\
\hline Leu & 120 & 122 & 123 & 123 & 6.1 \\
\hline Lys & 193 & 190 & 196 & 190 & 4.8 \\
\hline Met + Cys & 128 & 104 & 109 & 92 & 2.3 \\
\hline Phe + Tyr & 166 & 169 & 179 & 169 & 4.1 \\
\hline Thr & 179 & 177 & 183 & 194 & 2.5 \\
\hline Try & 430 & 433 & 256 & 282 & 0.66 \\
\hline Val & 115 & 116 & 114 & 111 & 4.0 \\
\hline His & 158 & 157 & 193 & 137 & 1.6 \\
\hline
\end{tabular}

${ }^{*}$ Recommended amino acid scoring pattern for adult.

TABLE 6: Essential amino acid content in muscle (g/100 g muscle) of grass carp, bighead carp, Siberian sturgeon, and wels catfish and the recommended daily intake for an adult man weighing $70 \mathrm{~kg}$.

\begin{tabular}{|c|c|c|c|c|c|c|}
\hline \multirow{2}{*}{ Amino acid } & \multicolumn{2}{|c|}{ Recommended daily intake* } & \multirow{2}{*}{ Grass carp } & \multirow{2}{*}{ Bighead carp } & \multirow{2}{*}{ Siberian sturgeon } & \multirow{2}{*}{ Wels catfish } \\
\hline & (mg/kg body weight) & (g/70 kg body weight) & & & & \\
\hline Thr & 6.5 & 0.46 & 0.88 & 0.79 & 0.80 & 0.80 \\
\hline Val & 11.4 & 0.80 & 0.91 & 0.83 & 0.80 & 0.74 \\
\hline Ile & 15.7 & 1.10 & 0.79 & 0.71 & 0.71 & 0.68 \\
\hline Leu & 9.5 & 0.67 & 1.44 & 1.33 & 1.31 & 1.25 \\
\hline Tyr + Phe & 12.1 & 0.85 & 1.33 & 1.24 & 1.29 & 1.15 \\
\hline Cys + Met & 12.1 & 0.85 & 0.58 & 0.43 & 0.44 & 0.35 \\
\hline Try & 2.9 & 0.20 & 0.56 & 0.51 & 0.30 & 0.31 \\
\hline Lys & 9.4 & 0.66 & 1.82 & 1.63 & 1.65 & 1.52 \\
\hline$\sum \mathrm{EAA}$ & 79.6 & 5.59 & 8.31 & 7.47 & 7.3 & 6.8 \\
\hline
\end{tabular}

${ }^{*}$ According to Gawęcki [42].

recommended daily intake for an adult man weighing $70 \mathrm{~kg}$ are presented in Table 6 . The sum of essential amino acids in $100 \mathrm{~g}$ of the muscle tissue of grass carp, bighead carp, Siberian sturgeon, and wels catfish was higher than the recommended daily intake. However, one has to point out the lower content of sulphur amino acids and isoleucine in all fish species analyzed as well as the lower valine content in wels catfish. Therefore, the recommended daily intake of all essential amino acids for an adult weighing $70 \mathrm{~kg}$ would require the consumption of $200 \mathrm{~g}$ of the muscle tissue of grass carp, bighead carp or Siberian sturgeon, or $250 \mathrm{~g}$ of wels catfish muscle tissue.

\section{Conclusion}

The four fish species examined in this study are characterized by high nutritional value and offer health benefits to consumers. However, the chemical composition of their muscle tissue is species-dependent. The muscle tissue of grass carp and wels catfish examined in this study had a lower caloric value than that of bighead carp and Siberian sturgeon, which may be useful in formulating a restricted calorie diet. Grass carp and wels catfish were classified as medium-fat fish, whereas bighead carp and Siberian sturgeon were categorized as fatty fish. The muscle tissue protein level was the highest in grass carp, but the quality of proteins was high in all species. All of them can serve as valuable sources of essential amino acids in terms of both quantity and quality.
The essential amino acid content in the protein of these fish was similar (for methionine + cysteine in wels catfish muscle) or even higher than that in the standard protein. Compared with the standard protein, the content of the limiting amino acid in muscle tissue was greater for grass carp, bighead carp, and Siberian sturgeon and similar for wels catfish. CS and PDCAAS confirmed the slightly lower value of protein in wels catfish muscle due to its lower content of methionine + cysteine. All four species, however, were particularly rich in lysine and tryptophan. These fish can constitute a healthy addition to the human diet, and the results obtained in this study can serve as a reference for nutritionists and dieticians.

\section{Data Availability}

The data used to support the findings of this study are available from the corresponding author upon request.

\section{Additional Points}

This study has documented the effect of fish species on the proximate composition, energy value, amino acid profile, and protein quality of the muscle tissue of grass carp, bighead carp, Siberian sturgeon, and wels catfish. The research results can serve as a reference for nutritionists and dieticians. 


\section{Conflicts of Interest}

The authors declare that they have no conflicts of interest.

\section{References}

[1] G. Özyurt and A. Polat, "Amino acid and fatty acid composition of wild sea bass (Dicentrarchus labrax): a seasonal differentiation," European Food Research and Technology, vol. 222, no. 3-4, pp. 316-320, 2006.

[2] Z. Tzikas, I. Amvrosiadis, N. Soultos, and Sp. Georgakis, "Seasonal variation in the chemical composition and microbiological condition of Mediterranean horse mackerel (Trachurus mediterraneus) muscle from the North Aegean Sea (Greece)," Food Control, vol. 18, no. 3, pp. 251-257, 2007.

[3] L. Hadjinikolova, L. Nikolova, and A. Stoeva, "Comparative investigations on the nutritive value of carp fish meat (Cyprinidae), grown at organic aquaculture conditions," Bulgarian Journal of Agricultural Science, vol. 14, no. 2, pp. 127-132, 2008.

[4] Z. Usydus, J. Szlinder-Richert, M. Adamczyk, and U. Szatkowska, "Marine and farmed fish in the Polish market: Comparison of nutritional value," Food Chemistry, vol. 126, no. 1, pp. 78-84, 2011.

[5] M. R. Ghomi, A. Dezhabad, M. S. Dalirie et al., "Nutritional properties of kutum, Rutilus frisii kutum (Kamensky), silver carp, Hypophthalmichthys molitrix (Val.), and rainbow trout, Oncorhynchus mykiss (Walbaum), correlated with body weight," Archives of Polish Fisheries, vol. 20, no. 4, pp. 275280, 2012.

[6] D. Ljubojević, M. Ćirković, V. Đordević et al., "Fat quality of marketable fresh water fish species in the Republic of Serbia," Czech Journal of Food Sciences, vol. 31, no. 5, pp. 445-450, 2013.

[7] M. Naseri, M. Rezaei, S. Moieni, H. Hosseni, and S. Eskandari, "Effect of different precooking methods on chemical composition and lipid damage of silver carp (Hypophthalmichthys molitrix) muscle," International Journal of Food Science and Technology, vol. 45, no. 10, pp. 1973-1979, 2010.

[8] H. Karl, I. Lehmann, M. Manthey-Karl, C. Meyer, and U. Ostermeyer, "Comparision of nutritional value and microbiological status of new imported fish species on the German market," International Journal of Food Science and Technology, vol. 49, no. 11, pp. 2481-2490, 2014.

[9] P. Skałecki, M. Florek, A. Litwińczuk, A. Staszowska, and A. Kaliniak, "The nutritional value and chemical composition of muscle tissue of carp (Cyprinus carpio L.) and rainbow trout (Oncorhynchus mykiss Walb.) obtained from fish farms in the Lublin region," Scientific Annals of Polish Society of Animal Production, vol. 9, no. 2, pp. 57-62, 2013.

[10] P. Skałecki, M. Florek, A. Litwińczuk, and A. Zaborska, "Utility value and meat quality of rainbow trout (Oncorhynchus mykiss) with regard to the weight of fish," Scientific Annals of Polish Society of Animal Production, vol. 9, no. 1, pp. 69-73, 2013.

[11] B. Mohanty, A. Mahanty, S. Ganguly et al., "Amino acid compositions of 27 food fishes and their importance in clinical nutrition," Journal of Amino Acids, vol. 2014, Article ID 269797, 7 pages, 2014.

[12] Report of an FAO Expert Consultation, "Dietary protein quality evaluation in human nutrition," FAO Food and $\mathrm{Nu}$ trition Paper, vol. 92, pp. 1-66, 2013.

[13] B. L. Oser, "Method for integrating essential amino acid content in the nutritional evaluation of protein," Journal of the
American Dietetic Association, vol. 27, no. 5, pp. 396-402, 1951.

[14] Report of Joint FAO/WHO Expert Consultation, "Protein quality evaluation," FAO Food and Nutrition Paper, vol. 51, pp. 1-66, 1991.

[15] PN-ISO 1442, "Meat and meat products-Determination of moisture content (Reference method)," 2000.

[16] PN-ISO 1444, "Meat and meat products-Determination of free fat content," 2000.

[17] PN-ISO 936, "Meat and meat products-Determination of total ash,” 2000.

[18] PN-A-04018, "Agricultural foods products. Determination of nitrogen by the Kjeldahl method and expressing as protein," 1975.

[19] PN-ISO 3496, "Meat and meat products-Determination of hydroxyproline content," 2000.

[20] M. G. Davies and A. J. Thomas, "An investigation of hydrolytic techniques for the amino acid analysis of foodstuffs," Journal of the Science of Food and Agriculture, vol. 24, no. 12, pp. 1525-1540, 1973.

[21] E. Schram, S. Moor, and E. J. Bigwood, "Chromatographic determination of cystine as cysteic acid," Biochemical Journal, vol. 57, no. 1, pp. 33-37, 1954.

[22] P. Sławiński and K. Tyczkowska, "Conditions for the hydrolysis of fodder raw materials and products in determining tryptophan," Roczniki Technologii i Chemii Żywności, vol. 24, pp. 155-163, 1974.

[23] S. W. Souci, W. Fachmann, and H. Kraut, Food Composition and Nutrition Tables, Medpharm Scientific Publishers, Stuttgart, Germany, 2000.

[24] H. Wedekind, "Chemical composition and processability of farmed sturgeon hybrids with special emphasis on Bester," International Review of Hydrobiology, vol. 87, no. 5-6, pp. 621-627, 2002.

[25] B. Jankowska, Z. Zakęś, T. Żmijewski, and M. Szczepkowski, "A comparison of selected quality features of the tissue and slaughter yield of wild and cultivated pikeperch Sander lucioperca (L.)," European Food Research and Technology, vol. 217, no. 5, pp. 401-405, 2003.

[26] T. Larsson, E. O. Koppang, M. Espe et al., "Filet quality and health of Atlantic salmon (Salmo salar L.) fed a diet supplemented with glutamate," Aquaculture, vol. 426-427, pp. 288-295, 2014.

[27] PN-A-86770, "Fish and fishery products-Terminology," 1999.

[28] A. Badiani, P. Anfossi, L. Fiorentini et al., "Nutritional composition of cultured sturgeon (Acipenser spp.)," Journal of Food Composition and Analysis, vol. 9, no. 2, pp. 171-190, 1996.

[29] M. Afkhami, A. Mokhlesi, K. D. Bastami, R. Khoshnood, N. Eshaghi, and M. Ehsanpour, "Survey of some chemical compositions and fatty acids in cultured common carp (Cyprinus carpio) and grass carp (Ctenopharyngodon idella), Noshahr, Iran," World Journal of Fish and Marine Sciences, vol. 3, no. 6, pp. 533-538, 2011.

[30] R. Scherer, P. R. Augusti, V. C. Bochi et al., "Chemical and microbiological quality of grass carp (Ctenopharyngodon idella) slaughtered by different methods," Food Chemistry, vol. 99, no. 1, pp. 136-142, 2006.

[31] B. Jankowska, R. Kolman, M. Szczepkowski, and T. Żmijewski, "Production value, chemical composition and colour of fillets of the reciprocal hybrid of Siberian sturgeon with green sturgeon (Acipenser baerii $\mathrm{Br} \times$ (Acipenser baerii x Acipenser medirostris Ayres)," Czech Journal of Animal Science, vol. 50, no. 5, pp. 220-225, 2005. 
[32] E. S. Lazos, G. Aggelousis, and A. Alexakis, "Metal and proximate composition of the edible portion of 11 freshwater fish species," Journal of Food Composition and Analysis, vol. 2, no. 4, pp. 371-381, 1989.

[33] A. Öksüz, A. Küçükgülmez, A. Diler, M. Çelik, and E. Koyuncu, "Research note: A comparison of the chemical composition of zander (Sander lucioperca) living in different lakes of Turkey," Journal of Muscle Foods, vol. 20, no. 4, pp. 420-427, 2009.

[34] M. Ćirković, D. Trbović, D. Ljubojević, and V. Đordević, "Meat quality of fish farmed in polyculture in carp ponds in Republic of Serbia," Tehnologija Mesa, vol. 52, no. 1, pp. 106-121, 2011.

[35] S. Yeganeh, B. Shabanpour, H. Hosseini, M. R. Imanpour, and A. Shabani, "Comparison of farmed and wild common carp (Cyprinus carpio): Seasonal variations in chemical composition and fatty acid profile," Czech Journal of Food Sciences, vol. 30, no. 6, pp. 503-511, 2012.

[36] F. Wang, X. Ma, W. Wang, and J. Liu, "Comparison of proximate composition, amino acid and fatty acid profies in wild, pond- and cage-cultured longsnout catfish (Leiocassis longirostris)," International Journal of Food Science and Technology, vol. 47, no. 8, pp. 1772-1776, 2012.

[37] L. Polak-Juszczak and M. Adamczyk, "Quality and amino acid composition of protein of fish from the Vistula Lagoon," Żywność Nauka Technologia Jakość, vol. 64, no. 3, pp. 75-83, 2009.

[38] O.O. Oluwaniyi, O. O. Dosumu, and G. V. Awolola, "Effect of local processing methods (boiling, frying and roasting) on the amino acid composition of four marine fishes commonly consumed in Nigeria," Food Chemistry, vol. 123, no. 4, pp. 1000-1006, 2010.

[39] G. S. El oudiani and N. Moujahed, "Atlantic mackerel amino acids and mineral contents from the Tunisian middle eastern coast," International Journal of Agricultural Policy and Research, vol. 3, no. 2, pp. 77-83, 2015.

[40] E. I. Adeyeye, "Amino acid composition of three species of Nigerian fish: Clarias anguillaris, Oreochromis niloticus and Cynoglossus senegalensis," Food Chemistry, vol. 113, no. 1, pp. 43-46, 2009.

[41] G. Schaafsma, "The protein digestibility-corrected amino acid score," Journal of Nutrition, vol. 130, no. 7, pp. 1865-1867, 2000.

[42] J. Gawęcki, Białka w żywności i żywieniu, WAR Publisher, Poznań, Poland, 2003. 


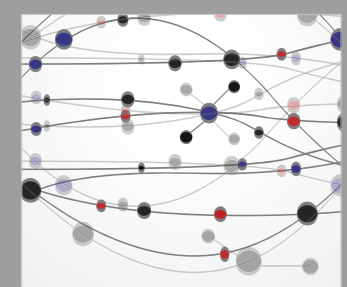

The Scientific World Journal
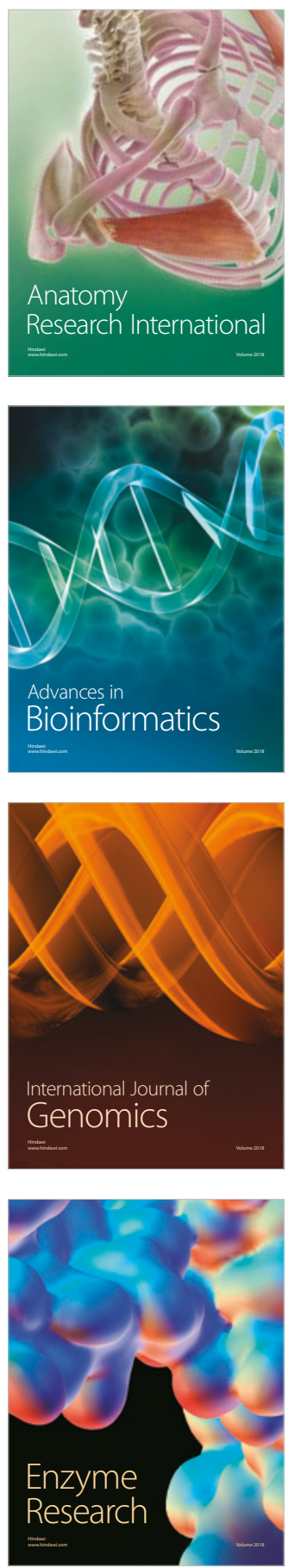
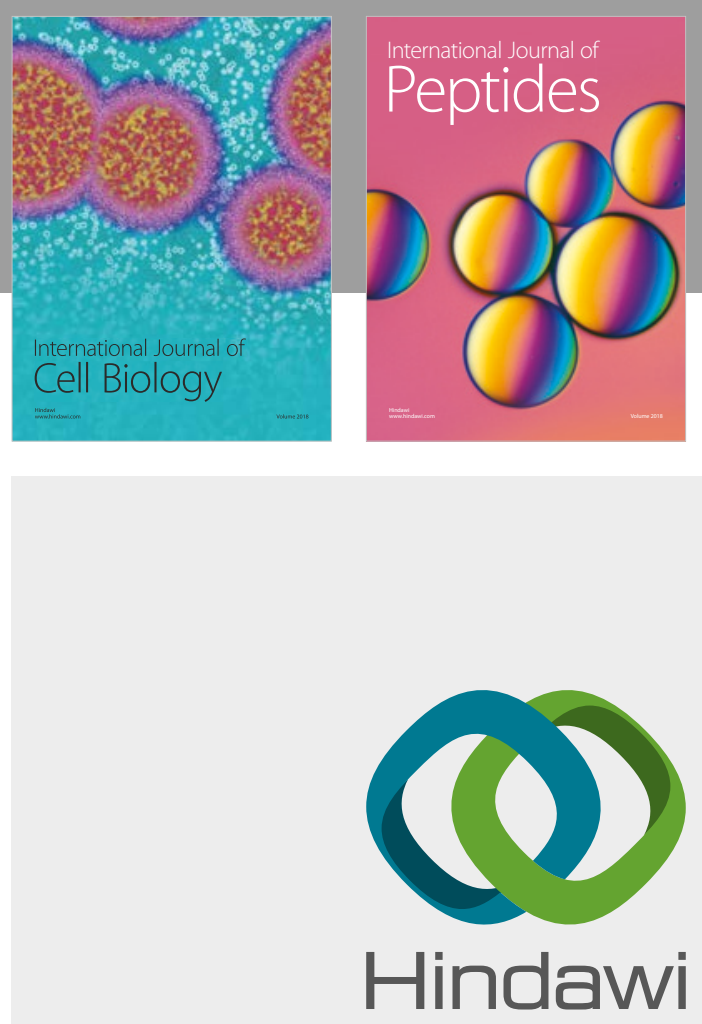

Submit your manuscripts at

www.hindawi.com
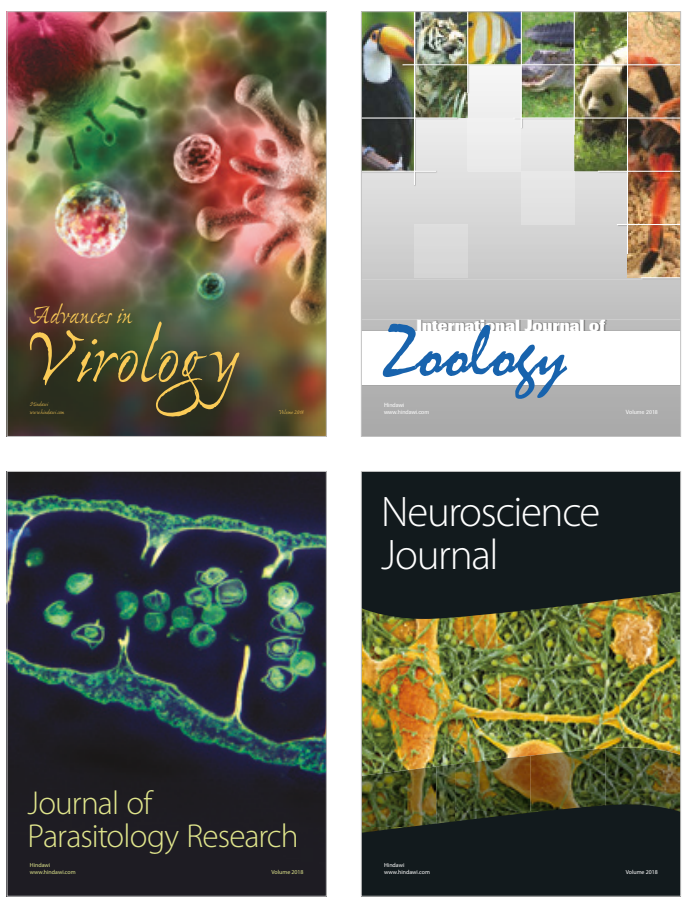
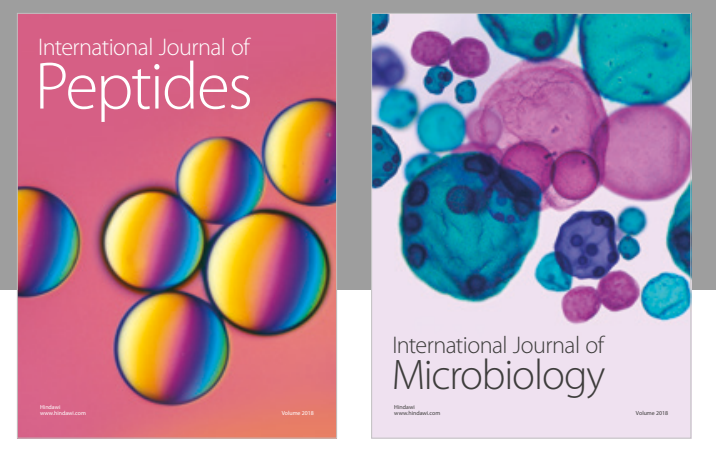

nternational Journal of Microbiology
Journal of
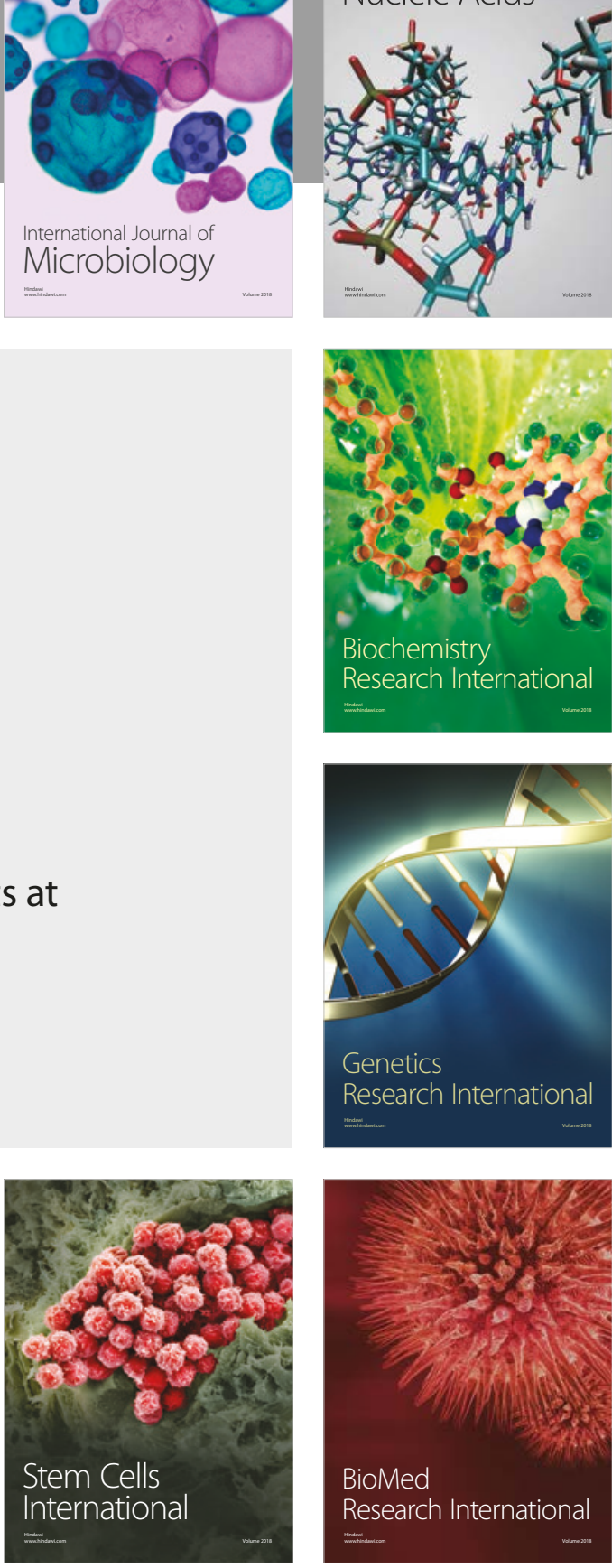
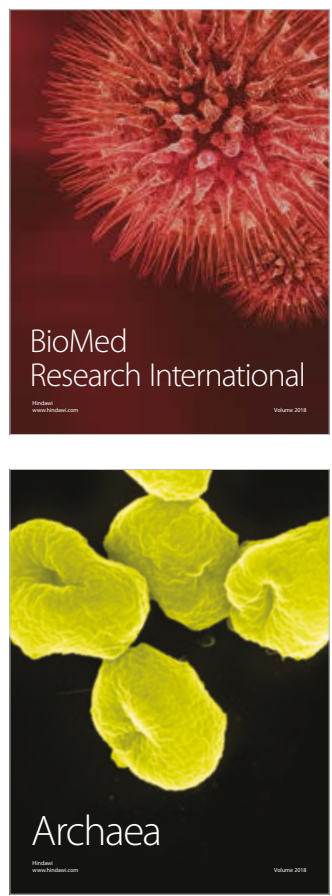